Recherches en histoire de l'art, histoire des civilisations, archéologie, anthropologie et muséologie

$8 \mid 2016$

Cahiers 8

\title{
Writing about displays of sculpture: historiography and some current questions
}

\section{Malcolm Baker}

\section{OpenEdition}

\section{Journals}

Electronic version

URL: http://journals.openedition.org/cel/332

DOI: $10.4000 /$ cel.332

ISSN: 2262-208X

\section{Publisher}

École du Louvre

\section{Electronic reference}

Malcolm Baker, «Writing about displays of sculpture: historiography and some current questions », Les Cahiers de l'École du Louvre [Online], 8 | 2016, Online since 01 May 2016, connection on 17 September 2019. URL : http://journals.openedition.org/cel/332 ; DOI : 10.4000/cel.332

\section{c) $(1) \Theta$}

Les Cahiers de l'École du Louvre sont mis à disposition selon les termes de la licence Creative Commons Attribution - Pas d'Utilisation Commerciale - Pas de Modification 4.0 International. 


\section{Writing about displays of sculpture: historiography and some current questions.}

\section{Malcolm Baker}

The current interest in how museums have displayed sculpture at different points in their history - the subject of the study day celebrating the reconfiguration of the Musée Rodin's displays - forms part of a wider set of questions about how sculpture has been displayed and viewed historically. This paper will survey the development of this field of enquiry over the past thirty years or so and outline what I see as some of the key questions about the display and viewing of sculpture that we are addressing now. One central issue that any curator of sculpture has to confront is this: how are works of sculpture which were created for specific settings - often public settings - to be shown meaningfully in gallery displays which impose their own new viewing conditions and lock these sculptures into a new set of narratives? How do both curators and spectators engage with sculptures which were once site-specific but which are now de-contextualized or rather re-contextualized as gallery sculptures? For works which were envisaged from the start as sculptures to be displayed in galleries - figures executed for the Salon of the Académie or groups intended for those sculpture galleries that were created from the eighteenth century onwards for the sole purpose of displaying sculpture - the tension may not be too great. But for devotional images which formed part of larger ensembles such as altarpieces or monuments designed from the start for a public, exterior and urban setting, the challenges are much more formidable, as any sculpture curator knows. To address these issues, it might be helpful to examine the way in which the display and viewing of sculpture has been considered in the literature of art history over the past thirty years and the questions that various innovative studies have raised.

But first I should briefly mention some wider shifts in art historical practice which I see as informing recent work on the display and viewing of sculpture. Among these has been a concern with the wider social function of works of art, as articulated through a social history of art. At the same time, a new interest has developed in the histories of institutions which have shaped both the production and viewing of art, not only the academy but (especially) the art museum and its exhibitions. Associated with this has been the emergence of the history of collecting and display as a subfield of art history. Such developments may also be related to another shift - the shift of emphasis from the creation of works of art to their reception, from the artist to the viewer. From another perspective, this might be understood in terms of the phenomenology of viewing. Yet another significant area of activity has been concerned with responses to materials and materiality. These, then, are just a few of the characteristics of the discipline of art history as it is currently practised.

Against this rather crude background sketching out general changes in art historical methodology, I should now like to outline a number of new approaches that have focused attention more specifically on the history of sculpture display and viewing, each of which I shall illustrate with some examples. And here - I should stress - I am not offering a comprehensive overview of the large literature but just picking out some cases which have interested me. With this proviso, these approaches might be summarized under five headings, overlapping though these are.

\section{Histories of collecting and the display of sculpture}

As part of the development of the history of collecting and display as a distinctive field, the display of sculpture has received increasing attention. In particular (and unsurprisingly) classical sculpture and its afterlives (often in successive collections) have been intensively studied. Even though its central argument 
concerned the reception of antique sculpture and the construction of a classical canon, the ground-breaking study by Francis Haskell and Nicholas Penny (Taste and the Antique) included a mass of information about where antique statuary was "displayed" from the Renaissance onwards. ${ }^{1}$ Since then, Kathleen Wren Christian has given us a far fuller analysis of the formation and disposition of collections of antique sculpture in Renaissance Rome. ${ }^{2}$ But in addition some of the most important individual locations have received detailed and sustained studies. I am thinking here, for instance, of the Villa Albani, about which the Liebieghaus published a major multi-authored study in the 1980 s. $^{3}$ More recently the placing of sculpture at the Villa Borghese has been addressed in several studies, among them Kristina Hermann Fiori on the setting of reliefs on the façade and Carole Paul on its interiors. ${ }^{4}$ A major research project (and an associated exhibition) about the Palazzo Pitti has led to the virtual reconstruction of the Hall of the Niches while the Getty Research Institute's work on seventeenth-century Roman palaces has revealed how antique sculpture was displayed in Queen Christina's Roman palace. ${ }^{5}$ Elsewhere, the Antikensaal in Munich has received new attention as a display of sculpture, rather than just as a collection, and scholars such as Carole Paul and Jeffrey Collins have allowed us to see the Capitoline Museum and the Museo Pio-Clementino in new ways. ${ }^{6}$ But back in the early 1980s, in hommage to the classical collections in Munich, one pioneering set of essays on the display of antique sculpture had already been published by the Glypthotek in Munich. Here the study of early settings was complemented by a concern with later re-contextualization, not least in the Glyptothek itself. ${ }^{7}$

Nowhere, other than Rome, has the collecting and display of antique has been more intensively explored than in studies of the British country house. The scholarly precursor to modern studies was of course Gustav Waagen's account of classical sculpture in British collections produced in the mid-nineteenth century. In the later twentieth century this tradition of German archaeological zeal has been continued by their successors in Frankfurt and Cologne and more recently these collections have been subjected to a broader cultural interpretation in studies such as Dietrich Boschung and Henner von Hesberg's volume, Antikensammlungen des europäischen Adels im 18. Jahrhundert als Ausdruck einer europäischen Identität. ${ }^{8}$ (This includes Jens-Arne Dickmann's acute analysis of the collection once displayed at Wilton House.) But much more recently the collections at houses such as Holkham, Chatsworth and Woburn, and Wilton have been systematically investigated with the help of detailed work on the substantial archival sources (fig. 1). Some writings - such as the late Jonathan Scott's The Pleasures of Antiquity - have concentrated on the collecting activities

1. Francis Haskell and Nicholas Penny, Taste and the Antique, New Haven and London, Yale University Press, 1980.

2. Kathleen Wren Christian, Empire without end: antiquities collections in Renaissance Rome, c. 1350-1527, New Haven and London, Yale University Press, 2010.

3. Forschungen zur Villa Albani: antike Kunst und die Epoche der Aufklärung, Herbert Beck and Peter C. Bol eds., Berlin, Mann, 1982; Forschungen zur Villa Albani: katalog der antiken Bildwerke, P.C. Bol ed., 5 vols, Berlin, Mann, 1989-1998.

4. Kristina Hermann Fiore, "The outdoor exhibition of sculpture on the Villa Borghese facades in the time of Cardinal Scipione Borghese", in Collecting sculpture in early modern Europe, acts of symposium, 7.2.-8.2.2003, N. Penny and Eike D. Schmidt eds., Washington D.C., National Gallery of Art, 2008 (Studies in the history of art, 70), pp. 219-246; Carole Paul, The Borghese collections and the display of art in the age of the Grand Tour, Aldershot, Ashgate, 2008.

5. Palazzo Pitti: la reggia rilevata, Gabriele Capecchi ed., Firenze, Giunti, 2003; The Display of Art in the Roman Palace, 1550-1750, Gail Feigenbaum and Francesco Freddolini eds., Los Angeles, The Getty Research Institute, 2014.

6. Jeffrey Collins, "Museo Pio-Clementino, Vatican City: ideology and aesthetics in the age of the Grand Tour", and Carole Paul "The Museo Pio-Clementino", in The First modern museums of art: the birth of an institution in 18th- and early-19th-century Europe, Carole Paul ed., Los Angeles, J. Paul Getty Museum, 2012. Another exemplary study which should be mentioned here is Anne-Marie Leander Touati and Magnus Olausson, Ancient sculptures in the Royal Museum: the eighteenth-century collection in Stockholm, Stockholm, Swedish National Art Museums, Swedish Institute in Rome, 1998.

7. Glyptothek München 1830-1980, Klaus Viermeisel and Gottlieb Leinz eds., München, the Gallery, 1980.

8. Antikensammlungen des europäischen Adels im 18. Jahrhundert als Ausdruck einer europäischen Identität, acts of the international conference, Düsseldorf, 7.2.-10.2.1996, Dietrich Boschung and Henner von Hesberg eds., Mainz, von Zabern, 2000 (Monumenta artis Romanae, 27); Dirk Kocks, "Antikenaufstellung und Antikenergänzung im 18. Jahrhundert in England" in Antikensammlungen im 18. Jahrhundert, Herbert Beck and Peter C. Bol eds., Berlin, Mann, 1981 (Franfurter Forschungen zur Kunst), pp. 317-331. 
of successive generations of owners but others have paid as much if not more attention to the display of these collections.9 For example, Ruth Guilding's
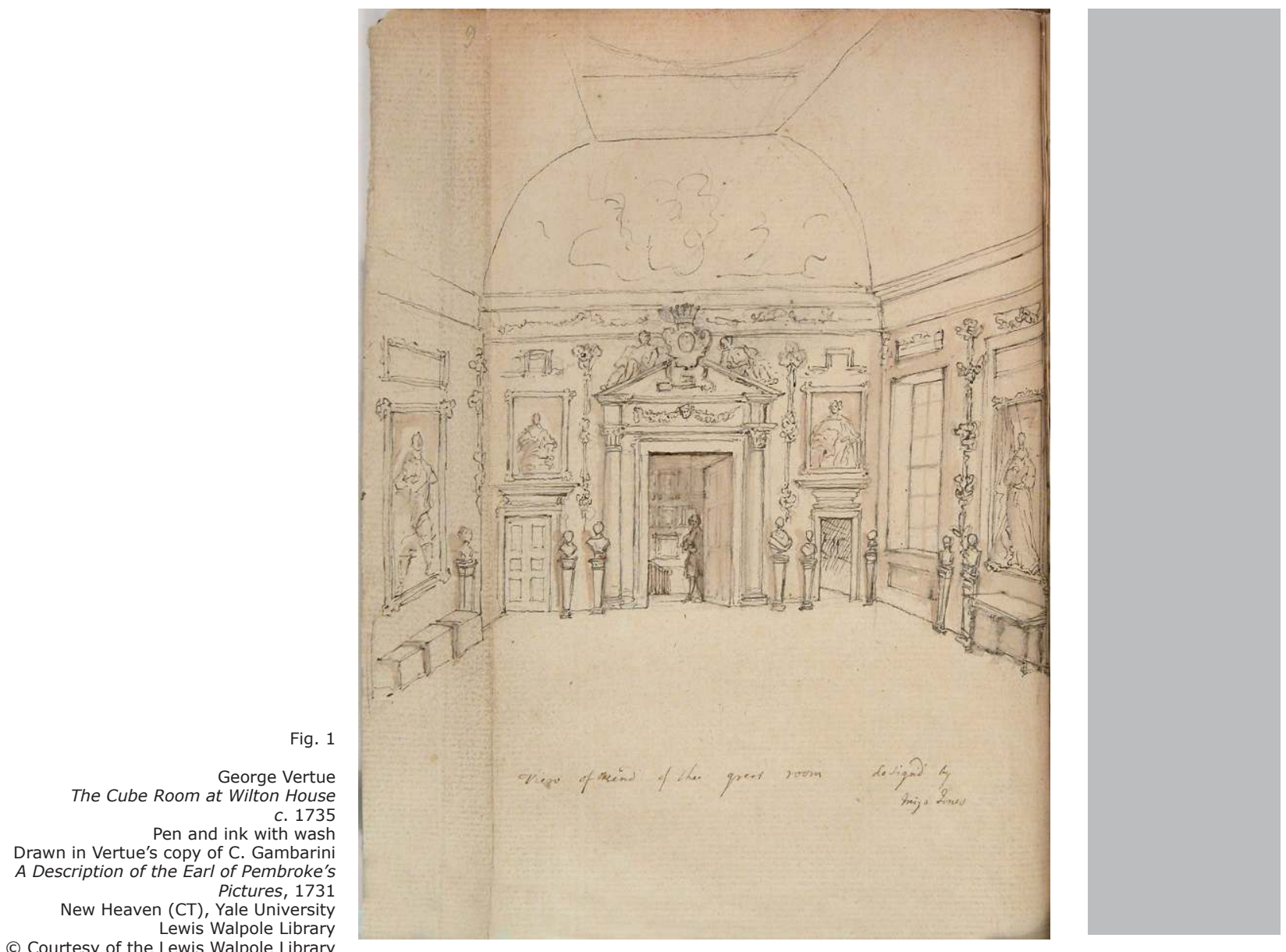

Marble Mania: Sculpture galleries in England 1640-1840 and, most recently, Owning the Past, and Vicky Coltman's Fabricating the Antique, in which the collecting and display of antique sculpture is interpreted as a means of constructing an elite masculinity. ${ }^{10}$ One pioneer here was John Kenworthy-Browne whose research on Newby, Woburn and Chatsworth mapped out a narrative tracking the emergence of the sculpture gallery - a space designed specifically and exclusively for the display of sculpture. ${ }^{11}$ Besides such publications, we have also seen some important refurbished displays. Recognition of the significance of these sculpture galleries and the rhetoric of their displays has in turn led to the restoration of some of these ensembles to their original state. While the contents of the gallery at Woburn remain dispersed, the collection at Chatsworth has been restored to its full glory in the original settings, stripped of later additions, so allowing us to appreciate the way in which early nineteenth-century works by the leading international sculptors, ranging from Canova and Thorvaldsen to Schwanthaler and Chantrey, could be combined in a single interior, the effect of their Carrara statuary marble set off against a variety of local stones. ${ }^{12}$

9. Jonathan Scott, The Pleasures of Antiquity: British collectors of Greece and Rome, New Haven and London, Yale University Press, 2003.

10. Ruth Guilding, Marble Mania: sculpture galleries in England 1640-1840: the Soane Gallery 2001, London, Sir John Soane's Museum, 2001; eadem, Owning the past: why the English collected antique sculpture, 1640-1840, New Haven and London, Yale University Press, 2014; Vicky. Coltman, Fabricating the antique: neoclassicism in Britain, 1760-1800, Chicago, University of Chicago Press, 2006.

11. John Kenworthy-Browne, "Privaten Skulpturen-galerien in England 1730-1830", in Glyptothek München, op. cit. note 7, pp. 334-353; idem, "A Ducal Patron of Sculpture", Apollo, 96 (1972), pp. 332-331; idem, "The Third Earl of Egremont and Neo-Classical Sculpture", Apollo, 105 (1977), pp. 367-373.

12. Alison Yarrington, "Marble, memory and theatre: portraiture and the Sculpture Gallery at Chatsworth", in Placing faces: the portrait and the English country house in the long eighteenth century, Gill Perry, Kate Retford, Jordan Vibert with Hannah Lyons eds., Manchester and New York, Manchester University Press, 2013, pp. 96-114. 
Much of this work on the display of sculpture in English country houses has been done against the background of studies on the history of the interior - almost a distinct sub-field of material and cultural studies. This domain was pioneered by the furniture historian Peter Thornton and the architectural historian John Cornforth, concentrating on the history of furniture and the role of furnishings in the interior. ${ }^{13}$ Though sculpture has been largely ignored in such studies, the approach and methodology of such scholars has increasingly informed how sculpture historians have thought about the display of collections in interiors. ${ }^{14}$ Conversely, the contribution of sculpture historians may offer new possibilities for the way that historians of the interior think about interiors as integral ensembles in which sculpture might play a key and in some cases even dominating role; this needs to be taken account in discussions of the social and ritual interactions which took place in such spaces.

Questions about displaying sculpture of another sort - small-scale sculpture have been prompted by the increasing number of studies about the Wunderkammer. Building on pioneering texts by Julius von Schlosser, scholars such as Thomas DaCosta Kaufmann, Christian Theuerkauff and Eicke Schmidt among others have shown how the Wunderkammer provided a meaningful context in which ivory sculpture might have been displayed and viewed. ${ }^{15}$ As a material which was crafted in a virtuoso manner, ivory in the form of Kleinplastik was an ideal medium for combining the natural and manmade, the juxtaposition of which lay at the heart of the Wunderkammer or "cabinet of curiosities". Coming into the art-historical mainstream with Oliver Impey and Arthur MacGregor's influential volume, The Origins of Museums, the Wunderkammer and its Kleinplastik have remained of central concern not only in studies of collections such as Schloss Ambras and the Grunes Gewölbe but also in accounts by both Debora Meijers (in her Kunst als Natur) and Thomas DaCosta Kaufmann of how the Hapsburg collections were reconfigured in the eighteenth century. ${ }^{16}$

Another category of sculpture the collecting of which has been considered in its own right is the small bronze. Pioneering studies by Detlef Heikamp of the Medici collections illuminated the role played by bronze sculpture in, for instance, the Studiolo of Francesco I, and more recently the way in which bronzes outside Italy were displayed has attracted attention. ${ }^{17}$ Along with the study of the bronzes acquired for the British royal collection and the way they were displayed - David Howarth has led the way here - we had a detailed examination (and a revealing exhibition in Paris) about the Bronzes de la Couronne. ${ }^{18}$ But there are areas still due for detailed investigation. Interesting questions remain to be asked, for instance, about what can be learned from the celebrated prints of bronzes and other sculptures in Girardon's collection. Also, in the case of portable objects such as bronzes we have the opportunity to explore the movement of sculptures through several different collections. Take this signed Giambologna bronze which we can track from its appearance in the posthumous inventory of Nicolo Gaddi,

\footnotetext{
13. Peter Thornton, Seventeenth-century interior decoration in England, France, and Holland, New Haven and London, Yale University Press, 1978; John Cornforth, Early Georgian interiors, New Haven and London, Yale University Press, 2004; Jeremy Aynsley and Charlotte Grant, Imagined interiors: representing the domestic interior since the Renaissance, London and New York, V\&A Publications, 2006 (a V\&A-RCA research project)

14. Some of the implications for sculpture historians have been explored in Malcolm Baker, The Marble Index, New Haven and London, Yale University Press, 2014.

15. Julius von Schlosser, Die Kunst- und Wunderkammern der Spätrennaissance, Lepizig, Klinkhardt \& Biermann, 1908 (new ed., Braunschweig, Klinkhardt \& Biermann, 1978); E. Schmidt, "Cardinal Ferdinando, Maria Maddalena of Austria, and the early history of ivory sculptures at the Medici court", in Collecting Sculpture, op. cit. note 4, pp. 159-183.

16. The Origins of museums: the cabinet of curiosities in sixteenth- and seventeenth century Europe, Oliver Impey and Arthur MacGregor eds., Oxford, Clarendon Press, 1985; Debora Meijers, Kunst als Natur: die Habsburger Gemäldegalerie in Wien um 1780, Wien, Kunsthistorisches Museum, 1995 (Schriften des Kunsthistorischen Museums, 2); Thomas. DaCosta Kaufmann, "From treasury to museum: the collections of the Austrian Habsburgs", in The Cultures of collecting, John Elsner and Roger Cardinal eds., London, Reaktion Books, 1994, pp. 137-154.

17. Detlef Heikamp, "La Tribuna degli Uffizi come era nel Cinquecento", Antichita Viva, 3 (1964), pp. 11-30; idem, "Zur Geschichte de Uffizien-Tribuna and der Kunstschränke in Florenz und Deutschland", Zeitschrift für Kunstgeschichte, 26 (1963), pp. 193-268.

18. David Howarth, "Charles I, sculpture and sculptors", in The Late King's Goods: collections, possessions, and patronage of Charles I in the light of the Commonwealth sale inventories, Arthur MacGregor ed., London, Oxford University Press, 1989, pp. 73-113; Les Bronzes de la Couronne, Sophie Baratte ed., exh. cat., Paris, Louvre, 12.4.-12.7.1999, Paris, Réunion des musées nationaux, 1999.
} 
who had placed it in a window on a porphyry column, to the early nineteenthcentury collection of William Beckford, who had it shown among a group of other precious objects and displayed it on the chimney-piece of his drawing room in Bath (fig. 2). ${ }^{19}$ In this case, we get a glimpse of the importance of the bases, plinths, pedestals and socles on which sculptures were placed. The most celebrated case is of course Michelangelo's base for the statue of Marcus Aurelius but much more attention has recently been paid to the very varied forms of base and pedestal in later periods. Despite notable contributions by Nicholas Penny, Ian Wardropper and Étienne Jollet, the way in which sculptures were supported (and the way these bases, plinths and socles were sometimes changed) deserves the same level of scrutiny which has for some time been accorded to the relationship between paintings and frames. ${ }^{20}$

Fig. 2 Giambologna Nessus and Deianira c. 1580 Henry E. Huntington Art Collections (c) Courtesy of the Huntington Art Collections San Marino (CA), California
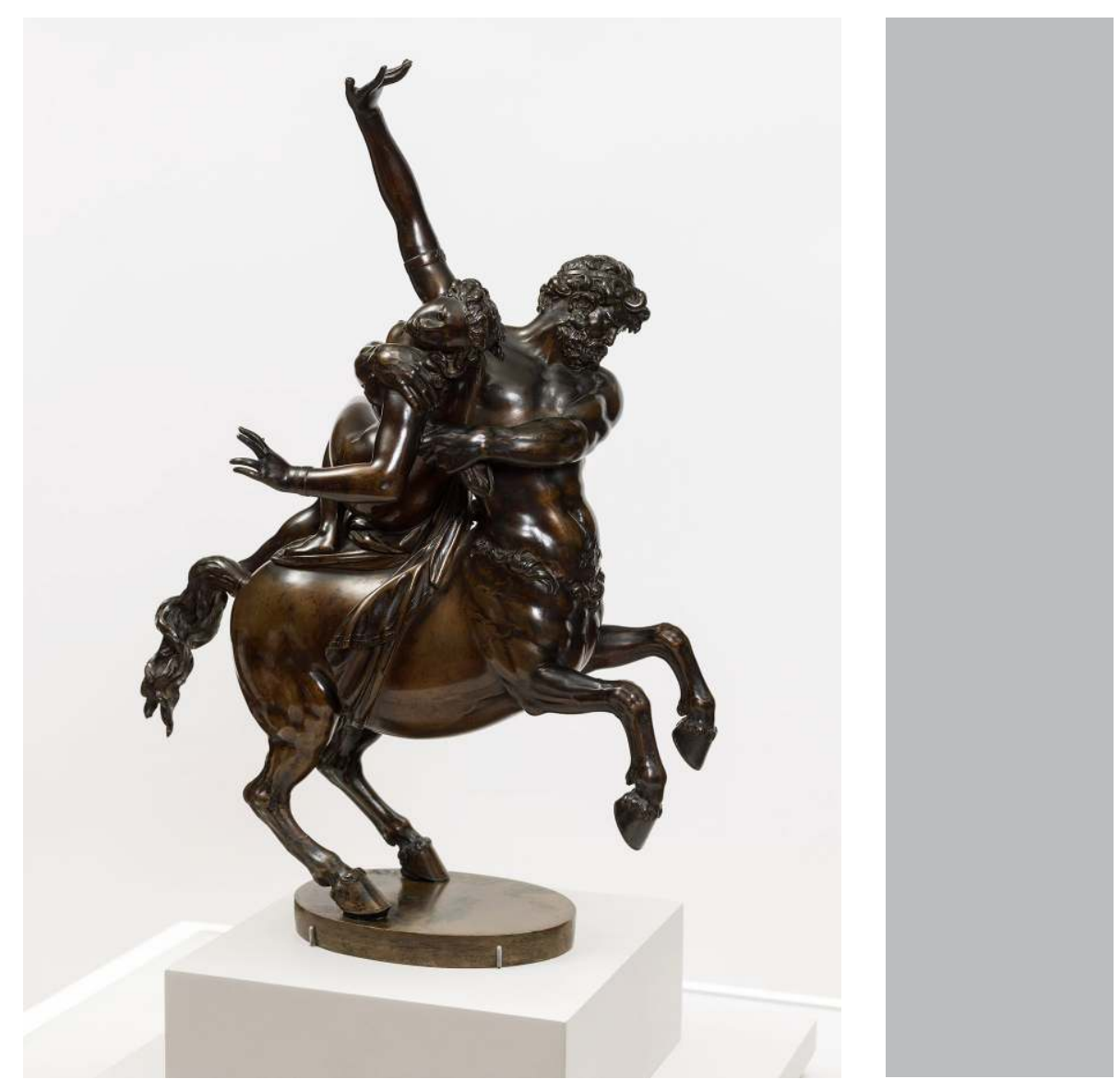

Underpinning much of this work have been some notable programmes of intensive archival research focused on specific collections. In some cases, such as Alden Gordon's monumental account of the Marquis de Marigny's houses and collections, the detailed analysis of inventories has involved a large and diverse collection of which sculpture formed but one part. ${ }^{21}$ But when sculpture is contextualized in this way, its role within a larger collection emerges more clearly. In this particular case, Gordon's meticulous study complements the far more wide-ranging account by Colin Bailey of art patronage and collecting in

19. M. Baker, "Giambologna, Donatello and the sale of the Gaddi, Marucelli and Stosch bronzes", Städel Jahrbuch, N.F. 12 (1989), pp. 179-194.

20. N. Penny, "Evolution of the plinth, pedestal, and socle", in Collecting Sculpture, op. cit. note 4, pp. 461-481; Ian Wardropper, "'Pied destal ou sousbassement': displaying sculpture in Renaissance France", in ibidem, pp. 145-157; Display and Displacement. Sculpture and the pedestal from Renaissance to Post-Modern, Alexandra Gerstein ed., London, Holberton, 2007, including Etienne Jollet, "Objet d'attention. L'intérêt pour le support en France à l'époque moderne", pp. 33-60.

21. Alden R. Gordon, The Houses and Collections of the Marquis de Marigny, Los Angeles, The Provenance Index of the Getty Research Institute, 2003. For a stimulating account of the display of sculpture in eighteenth-century France, see Guilhem Scherf, "Collections et collectionneurs de sculptures modernes: un nouveau champ d'étude", in L'Art et les normes sociales au XVIIIe siècle, Thomas Gaehtgens ed., Paris, Éditions de la Maison des Sciences de I'Homme, 2001 (Passagen, 2), pp. 147-164 
which Marigny and his sculptural commissions also figure. ${ }^{22}$ In other cases, however, inventories have been mined in search of evidence about the sculpture in particular. The collecting and commissioning activities of the Rockingham family and the disposition of the sculpture - old and new, British and continental at Wentworth Woodhouse and their London house was explored by Nicholas Penny using the extensive family archives and the same source has more recently been used to different ends by Joan Coutu in her discussion of the family use of sculptural display as a political tool. Studies of the collecting and display of sculpture can be employed by a range of scholars with different methodological approaches. ${ }^{23}$

\section{Museology and the study of museum displays of sculpture}

One type of collection or setting requires particular attention because is here that we most frequently, or at least consciously, consider the question of how sculpture is displayed. This is what in the USA is described as the "art museum". The growing interest in the way that such institutions have constructed the past and have played a role not only in reflecting changing histories of art but also in actively shaping those histories has made us much more aware of what might be termed curatorial agency. This in its turn involves an awareness of the process of re-contextualisation. The burgeoning literature on the history of museums has made this an area of intense research and in these publications the place of sculpture is clearly recognized and not only in accounts of museums dedicated specifically to sculpture. Sculpture for example figures prominently in Andrew McClellan's Making the Louvre and Carole Paul's recent valuable collection of essays, The First Modern Museums of Art. ${ }^{24}$ Increasingly, major museums have been considering their pasts and looking at the ways that their collections (including their sculpture collections) were formed. And these acts of institutional retrospection have involved consideration of how objects, not least sculpture, were displayed. Take, for example, the Victoria and Albert Museum, London, with its collection of Italian sculpture or the Bayerisches Nationalmuseum in Munich, with its collection of German sculpture. Such displays did not remain static but were at points tellingly reconfigured and these changes may be tracked through archival photos and guidebooks - the archaeological evidence for museology.

The V\&A had been assiduously collecting Italian sculpture from the 1860s onward and by 1900 the collection was established as one of the foremost and wide-ranging collections in the world. According to a 1905 plan of the museum the Italian sculpture was prominently and separately shown in two large courts, divided according to material - marble, terracotta and bronze - in line with the institution's adherence to its original underlying principle as being a museum illustrative of the history of materials and techniques. Some fifty or so years later, the museum followed the shift made far earlier in German museums of arranging its ground floor galleries according to style periods. Following the reinstallation of the collections in the decade after the end of World War II, sculpture became integrated into displays combining different materials but sculpture dominated those galleries up to 1600 so that these rooms could easily be seen as sculpture galleries. As we shall see later, more fully integrated displays, with sculpture being presented more contextually were to appear only around $2000 .^{25}$

Sculpture displays of a very different sort were to be seen in the Bayerisches

22. Colin Bailey, Patriotic Taste: collecting modern art in pre-revolutionary Paris, New Haven and London, Yale University Press, 2002.

23. N. Penny, "Lord Rockingham's sculpture collection and the Judgment of Paris by Nollekens", J. Paul Getty Museum Journal, 19 (1991), pp. 5-34; Joan Coutu, "Sculpture and the forming of national tastes in the middle of the eighteenth century", in The "British" School of Sculpture, c.1760-1832, Sarah Burnage and Jason Edwards eds., Farnham, Ashgate, 2016 (British Art: Histories and Interpretations since 1700) (forthcoming).

24. Andrew McClellan, Inventing the Louvre, Cambridge, Cambridge University Press, 1999; idem, "Musée du Louvre, Paris: palace of the people, art for all", in Carole Paul, The First Modern Museums, op. cit. note 6, pp. 213-236.

25. For the development of the museum's displays see M. Baker and Brenda Richardson, A Grand Design: the art of the Victoria and Albert Museum, New York, Abrams, 1997. 
Nationalmuseum (fig. 3). Given the central place of German late Gothic wood sculpture in the BNM's collections it is not surprising that works by Riemenschneider and his contemporaries were given pride of place in the early displays, as shown in a photograph of about 1870 . Within rooms with neo-Gothic vaulting a mass of figures (many of which were originally part of larger ensembles) were placed on plinths, densely grouped, as if they were

Fig. 3

Display of works in Tilman Riemenschneider in the Bayersiches Nationalmuseum From Das Bayerische Nation 555-2005, 150 Jahre Sammeln, Forschen, Ausstellen, Hrsg. von Renate Eikelmann und Ingolf Bauer $(+)$, unter Mitarbeit on Birgitta Heid und Lorenz Seelig Hirmer-Verlag, München 2007 Inv.-Nr. Bibl. 6117, Foto Nr. D137527 (c) Das Bayerische Nationalmuseum Fotoaufträge und Reproduktionen
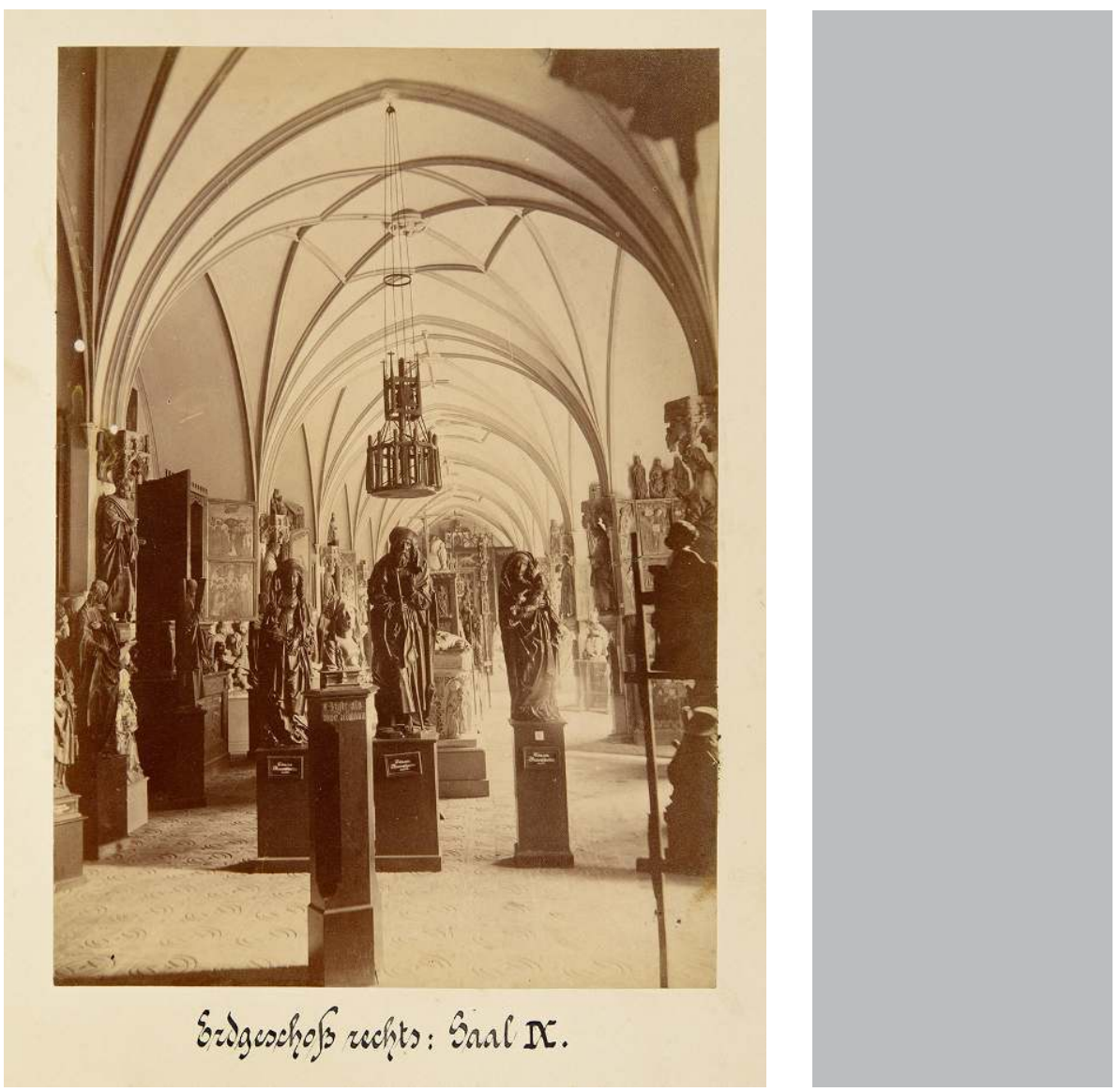

free-standing gallery sculptures. Despite the suggestion of a period setting through the architecture, the original settings, as well as the devotional functions, of these images were marginalised in favour of their qualities as autonomous sculptural objects. Of course, many of the Italian sculptures at the V\&A were similarly de-contextualised (or rather re-contextualised) but the narratives articulated by these two displays were different. While Italian Renaissance sculpture in London was presented as a component of a wider European art history, the works by South German sculptors in Munich were to be understood in terms of a national artistic achievement, with Riemenschneider being presented here as the sculptural equivalent of Dürer. This is a rather obvious, if not simplistic, point but the two displays prompt us to confront an equally obvious, but often ignored, feature of sculpture displays in museums. This is the way they frequently present sculptures taken from settings very different from galleries - settings in which they had functions other than the aesthetic roles with which they were invested through their re-contextualisation in museum galleries. This is hardly a new issue as it was central to the arguments advanced in the early nineteenth century by Louis-Pierre Deseine about the works taken from churches and displayed in the Musée des monuments français. ${ }^{26}$ But it remains pertinent to any consideration of how historical sculpture is shown in the museum and a broader discussion of sculptural display.

The proliferation of publications about the history and ideology of the museum and the many focused studies of particular institutions and their displays have

26. For discussion of Deseine see A. McClellan, Inventing the Louvre, op, cit note 24: Cecilia Hurley, Monuments for the people: Aubin-Louis Millin's Antiquités nationales (1790-1798), Turnhout, Brepols, 2013. 
allowed us to see these questions about the display of sculpture from a new perspective. Nowhere has this been more apparent then in the recognition of the importance of plaster casts as well as of the role played by reproductions more generally in the nineteenth-century museum. ${ }^{27}$ While surviving displays of casts are now relatively few - the restored display at Pittsburgh's Carnegie Museum is one of the few extensive collections other than that at the V\&A such assemblages were until the early twentieth century a familiar part of many large art museums, as Alan Wallach has shown. ${ }^{28}$ During the 1980 s - the period in which "appropriation" became familiar within contemporary practice - there was a renewed interest in such collections and their histories. Even more so than in the case of displays of original sculptures, the juxtaposition of so many reproductions of sculpture and architectural fragments throws into even sharper relief the museum's acts of de-contextualisation and re-contextualisation. So far I have been talking about the formation of collections of older or existing works and the different ways in these were displayed but what about the display of newly created works? Here the issue of setting and context is closely connected with function and use.

\section{The functions and uses of sculpture in its settings}

From the eighteenth century, at least some sculptures were made as aesthetically autonomous objects and primarily as works of art. (Take, for example, Canova's Three Graces and the "Temple of the Graces" designed for the group at Woburn. ${ }^{29}$ ) Some of these were intended for displays in spaces designed specifically and solely for the display of sculpture. But many more sculptures, especially from earlier periods, had other purposes and were intended for other types of setting. These were site-specific sculptures but the sites to which they were specific were not gallery spaces, posing challenges for curators who have to accommodate and make sense of such deracinated works within the new and perhaps alien contexts of the art museum.

Studies by historians as well as art historians have explored the role of statues of rulers in articulating political ideologies and increasingly such studies have stressed the significance that settings (usually public settings) had for the function of these works. Functions and settings have been a central concern in writing about other genres, whether devotional images, such as altarpiece, or busts, set up in series in libraries. Even when known as now isolated single figures or fragments, we today expect questions to be about a work's original function and setting as much as about its attribution and style.

Take some settings in which function is directly related to that setting. One consists of public settings such as the square in Reims where Pigalle's Louis XV was set up. Here studies by Jeffrey Merrick, Andrew McClellan, and Étienne Jollet have explored in different ways the affect that such images carried, as well as their overt political meanings and responses to them which may have been rather different from those intended. ${ }^{30}$ The same might be said of garden sculpture, whether at Vauxhall Gardens, with Roubiliac's statue of Handel, or

27. M. Baker, "The Reproductive Continuum: plaster casts, photographs, paper mosaics and alternative modes of reproduction in the nineteenth-century museum", in Plaster Casts: making, collecting and displaying from classical antiquity to the present, Rune Fredericksen and Eckart Marchand eds., Berlin, de Gruyter, 2010, pp. 485-500; Marjorie Trusted, "Reproduction as spectacle, education and inspiration: the 'Cast Courts' at the 'Victoria and Albert Museum': past, present and future", in Gipsabgüsse und antike Skulpturen: Präsentation und Kontext, Charlotte Schrieter ed., Berlin, Reimer, 2012, pp. 355-371, 387-388; Das Albertinum vor 100 Jahren: die Skulpturensammlung Georg Treus, Kordelia Knoll ed., Dresden, Staatliche Kunstsammlungen Dresden, 1994

28. Alan Wallach, Exhibiting Contradiction: essays on the art museum in the United States, Amherst, University of Massachusetts Press, 1998.

29. The Three Graces: Antonio Canova, Timothy Clifford et al. eds., Edinburgh, National Gallery of Scotland, 1995.

30. A. McClellan, "The Life and death of a royal monument: Bouchardon's Louis XV", Oxford Art Journal, 23 (2000), pp. 1-28; Jeffrey Merrick, "Politics on pedestals: royal monuments in eighteenth-century France", French History, 5 (1991), pp. 234-264; Étienne Jollet, "Between allegory and topography: the project for a statue to Louis XVI in Brest (1785-1786) and the question of the pedestal in public statuary in eighteenth-century France", Oxford Art Journal, 22 (2000), pp. 49-77. 
Versailles. ${ }^{31}$ Interestingly, the interpretation of garden sculptures from the reign of Louis XIV goes beyond that period, since studies of the afterlives of these images, as described in Geneviève Bresc's meticulous study of the sculpture in the Tuileries, shows that they may have been later read in very different ways. ${ }^{32}$ Understanding sculpture at Versailles also increasingly involves taking on what we learn from the developing field of "court studies" and those social rituals which took place around sculpture. (Michael Yonan, for example, has written especially interestingly about the way that sculpture worked within the architectural spaces of the Hapsburg court. ${ }^{33}$ ) A very different type of setting is found in the library. Recognizing the role that portrait busts of ancient and modern writers played in such settings is important, I suggest, if we are to understand that genre and its roles in the eighteenth century. ${ }^{34}$
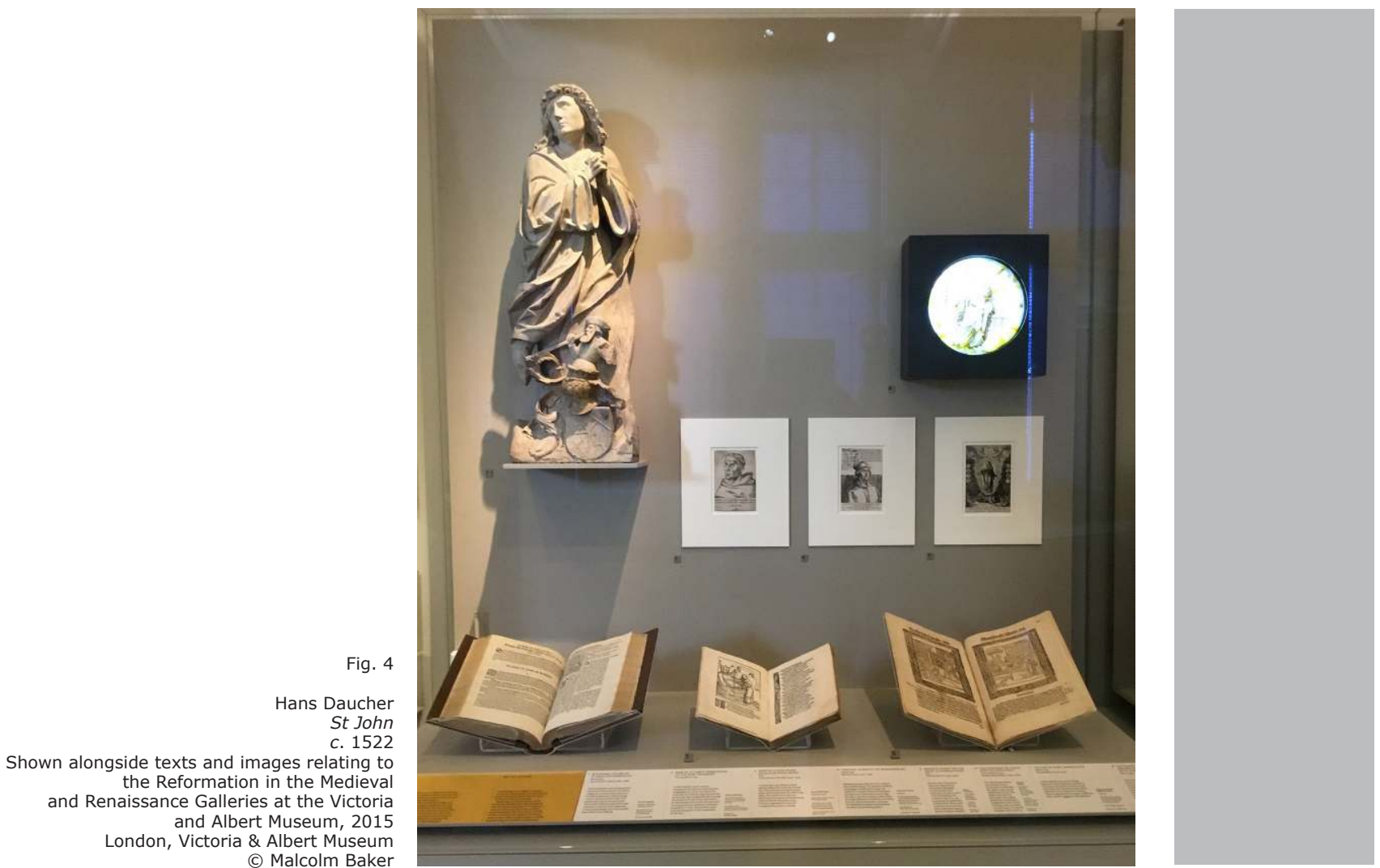

But there is of course a still more traditional use of sculptures, in very different settings; this is as devotional images in churches or in more private devotional contexts. Take Hans Daucher's St John - made as part of a crucifixion group to be set up in a church in Nuremberg by Lamparter von Greifenstein's son in memory of his father (fig. 4). Michael Baxandall has written eloquently about this work, using documentary evidence to explain its original purpose, going on to show that Lamparter's son decided not to put up the group in the church because of the hostility of the people of Nuremburg to images, just as the Reformation got underway. ${ }^{35}$ By contrast, the intricately carved Netherlandish rosary beads, later highly prized components of a Wunderkammer, were originally used in a far more private setting. The ritual uses of such images and the way they functioned to aid devotion in a variety of spaces have been explored by scholars such as Henk

31. David Bindman, "Roubiliac's statue of Handel and the keeping of order in Vauxhall Gardens in the early eighteenth century", Sculpture Journal, 1 (1997), pp. 22-31.

32. Geneviève Bresc-Bautier and Anne Pingeot, Sculptures des jardins du Louvre, du Carrousel et des Tuileries, Paris, Éditions de la Réunion des Musées nationaux, 1986 (Notes et documents des Musées de France, 12).

33. Michael Elia Yonan, "Modesty and monarchy: rethinking Empress Maria Theresa at Schönbrunn", Austrian History Yearbook, 35 (2004), pp. 25-47.

34. For the use of portrait sculpture in libraries, with references to earlier literature, see M. Baker, "The Portrait Sculpture", in The Making of the Wren Library, Trinity College, Cambridge, David McKitterick ed., Cambridge, Cambridge University Press, 1995, pp. 110-137.

35. Michael Baxandall, The Limewood Sculptors of Renaissance Germany, New Haven and London, Yale University Press, 1980. 
van Os, Frits Scholten and Reindert Falkenburg, not only in various books and articles but also in two exhibitions, one in Amsterdam and the other in Leeds. ${ }^{36}$ In this way, recent scholarship about the functions of images raised challenges, and in these two cases, prompted possible solutions by curators to deal with this issue.

\section{Materiality, process and the making of sculpture}

Another lively field of activity in sculpture studies has been that concerned with processes and circumstances of making. A more concentrated examination of workshop practices (often using sophisticated conservation and scientific tools) has opened up new questions about the role of models and sculptors' design processes. This has been associated with a series of important exhibitions, especially of sculptors' models. What were the uses of models and what of their afterlives? From the 1980s a series of exhibitions, often associated with ambitious conservation programmes, have addressed these issues, with varying emphases. Peter Volk's 1985 show at the Bayerisches Nationalmuseum about the remarkably rich range of South German sculptors' models in different materials showed the variety of forms models took and the way they were used while the exhibition about eighteenth-century terracottas, organized at the Louvre and the Metropolitan Museum by Guilhem Scherf and James Draper, paid new attention to the way in which such models were prized by later collectors. ${ }^{37}$ The continuing allure of such works for modern audiences was demonstrated by two shows of Bernini's models, the first at the Fogg Museum and a still more comprehensive one at the Metropolitan Museum.

Underpinning these richly collaborative undertakings has been a growing interest in the afterlife of these models - so not just their role in the process of creating sculpture but the way in which they were collected and displayed. Part of this history is the way that they were used, either for teaching or in the workshop by later sculptors. But increasingly there has been a concern with later collectors and how these models were shown within the context of different collections.

The collecting of models in both wax and terracotta has been seen to follow the pattern set by the collecting of drawings. Charles Avery has tracked how the Giambologna wax models prized by Vecchietti were later acquired by English collectors such as William Locke of Norbury and the late Dean Walker explored the wider history of collecting Italian models. ${ }^{38}$ Such discussions have draw on contemporary remarks such as that by Ange Laurent Lalive de Jully about terracottas retaining the fire of the original.

Collecting is one thing but display is not quite the same. It is more difficult to find evidence about how these were displayed and viewed. However, the sort of inventory studies which underpin the Getty Research Institute's project about the contents and displays within seventeenth- and eighteenth-century Roman palaces have produced some intriguing instances of how models were assembled in particular rooms, as if they were to be looked at together and in relationship to each other. ${ }^{39}$ What we do know rather more about, however, was the place that making, materials and process had in the Wunderkammer. The way in which lathes and other tools for making formed a distinctive feature of many Wunderkammern

\footnotetext{
36. The art of devotion in the late Middle Ages in Europe, 1300-1500, Henk Van Os et al. eds., London, Merrell Holberton, 1994; Frits Scholten and Reindert Falkenburg, A sense of heaven: 16th-century boxwood carvings for private devotion, Leeds, Henry Moore Institute, 1999.

37. Bayerische Rokokoplastik: Vom Entwurf zur Ausfuhrung, P. Volk ed., exh. cat., München, Bayerisches Nationalmuseum, 7.5.-21.7.1985, München, Bayerisches Nationalmuseum, 1985; James David Draper and Guilhem Scherf, L'esprit créateur de Pigalle à Canova: terres cuites européennes 1740-1840, exh. cat., Paris, Louvre, 19.9.2003-5.1.2004, Paris, Réunion des Musées nationaux, 2003.

38. Charles Avery, "Bernardo Vecchietti and the wax models of Giambologna", in La ceroplastica nella scienza e nell'arte: atti del I congresso internazionale, Firenze, 3 - 7 giugno 1975, Firenze, Olschki, 1977 (Biblioteca della "Rivista di storia delle scienze mediche e naturali", 20), 2, pp. 461476; Dean Walker, "Surveying the history of collecting Italian sculptural models", in From the sculptor's hand: Italian baroque terracottas from the State Hermitage Museum, Ian Wardropper dir., Chicago, Art Institute of Chicago, 1998, pp. 14-29.

39. Anne-Lise Desmas and Francesco Freddolini, "Sculpture in the palace: narratives of comparison, legacy and unity", in Display of art in the Roman Palace, op. cit. note 5, pp. 267-282.
} 
parallels the recognition by scholars such as Pamela Smith and Horst Bredekamp that, alongside published texts, knowledge of materials and processes was passed on through a tradition of artisanal knowledge. ${ }^{40}$ While not directly relating to sculptural practice, understanding materials, making and process in this way helps to inform how we make sense of sculptors' models and even how we display them.
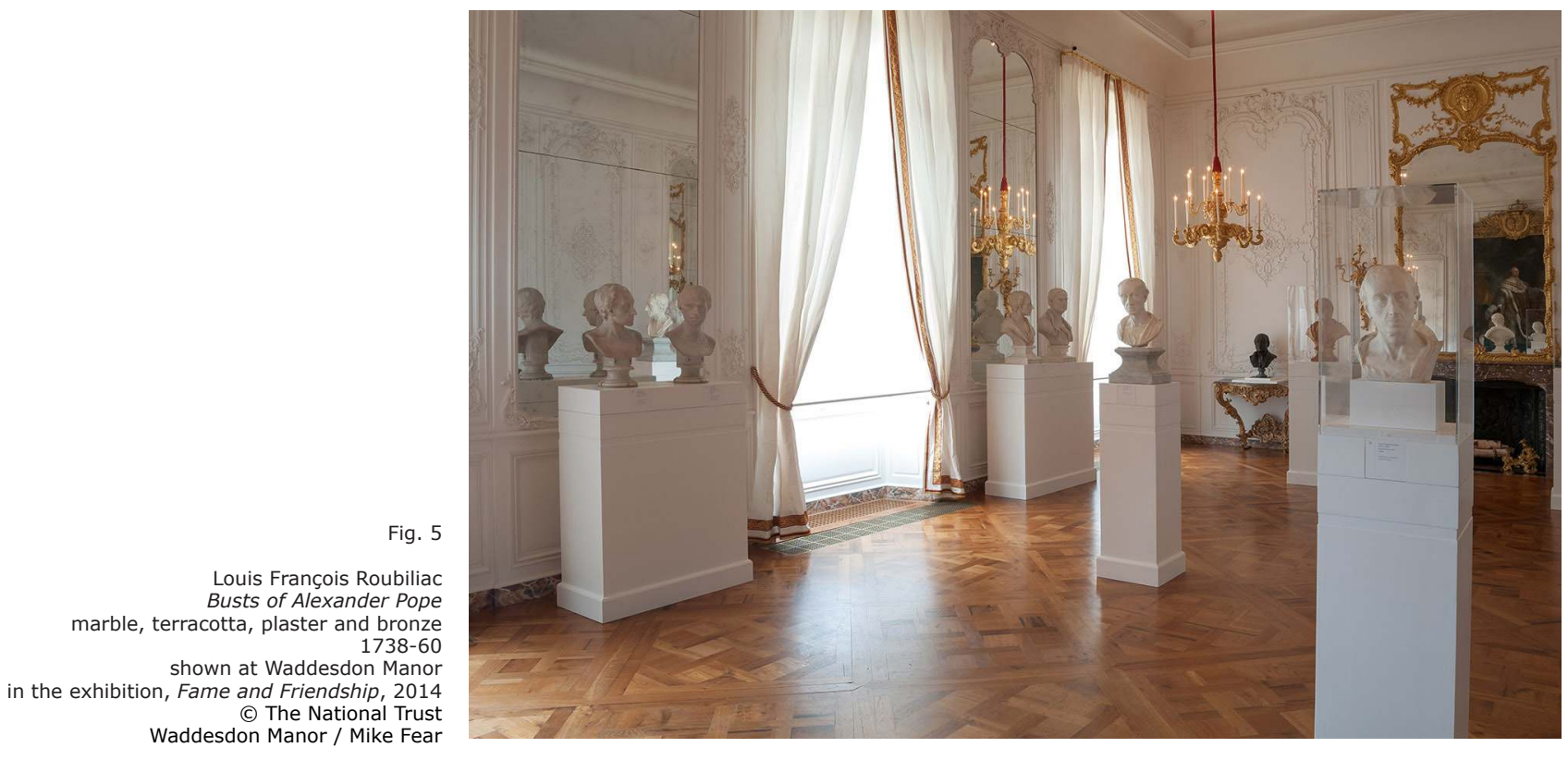

Alongside this work on workshop practices and the role of models has gone a renewed interest in processes of replication and the role of multiples, which raises further questions about different modes of display. In all areas of sculpture studies, it has been striking how much more nuanced our interpretation of copies, versions and multiples has become. An early sign of this was in the 1978 Giambologna exhibition, led by Anthony Radcliffe, Charles Avery and Manfred Leithe-Jasper, in which one long case contained seven different versions of the Mars figure. ${ }^{41}$ (Unsurprisingly, this long case became known to the curators as the Mars bar!) More recently, an exhibition I curated for the Yale Center for British Art, which involved a program of digital scanning by computer science colleagues at Yale, explored the complex relationship between eight different versions of Roubiliac's bust of the poet Alexander Pope and the ambiguous place of the one terracotta within this (fig. 5). ${ }^{42}$ In such exhibitions, the narrative of making in a sense lay between the various individual versions, linking them together in the viewer's mind. At the same time, the growing literature on sculptural multiples, such as the volume of essays recently edited by Walter Cupperi, has opened up new possibilities of understanding questions such as repetition, workshop collaboration and the dissemination of sculptural images. ${ }^{43}$ Understanding sculptural repetition is important whether we are thinking about Giambologna, Roubiliac or Donald Judd. (And this of course is a central theme here at the Musée Rodin as well as a theme that is explored so tellingly in the new displays.) In addition, we have seen a reassessment of those collections formed by sculptors, such as Canova, to memorialize their own achievements. In the case of Rodin, sculptural process and the celebration of a sculptor's career can happily be seen together.

40. Pamela Smith, The Body of the artisan: art and experience in the scientific revolution, Chicago, University of Chicago Press, 2006.

41. Giambologna, sculptor to the Medici, 1529-1608, Charles Avery and Anthony Radcliffe eds., Edinburgh and London, Arts Council of Great Britain, 1978.

42. M. Baker, Fame and Friendship: Pope, Roubiliac and the Portrait Bust, London, The Rothschild Foundation, 2013.

43. Multiples in Pre-Modern Art, Walter Cupperi ed., Zurich, Berlin, Diaphanes, 2014. 


\section{Responding to sculpture and its spaces}

So far I have been talking about the ways in which recent studies of sculpture have been engaged in different way with the issue of how sculpture was displayed or how sculpture was "staged". But the investigation of the settings in which sculptures were staged involves not only sculptor, patron and collector. It also requires consideration of the viewer and viewer's responses. Whether considering Bernini's groups in the Villa Borghese, Canova's Three Graces in the "Temple of the Graces" at Woburn or Donald Judd's aluminium Boxes in the Artillery Sheds at Marfa, Texas, sculpture historians have increasingly been concerned with the various modes of viewing open to a spectator but also that spectator's response to a sculpture within a shared space. New ways of writing about the apprehension of sculpture have been developed in the process.

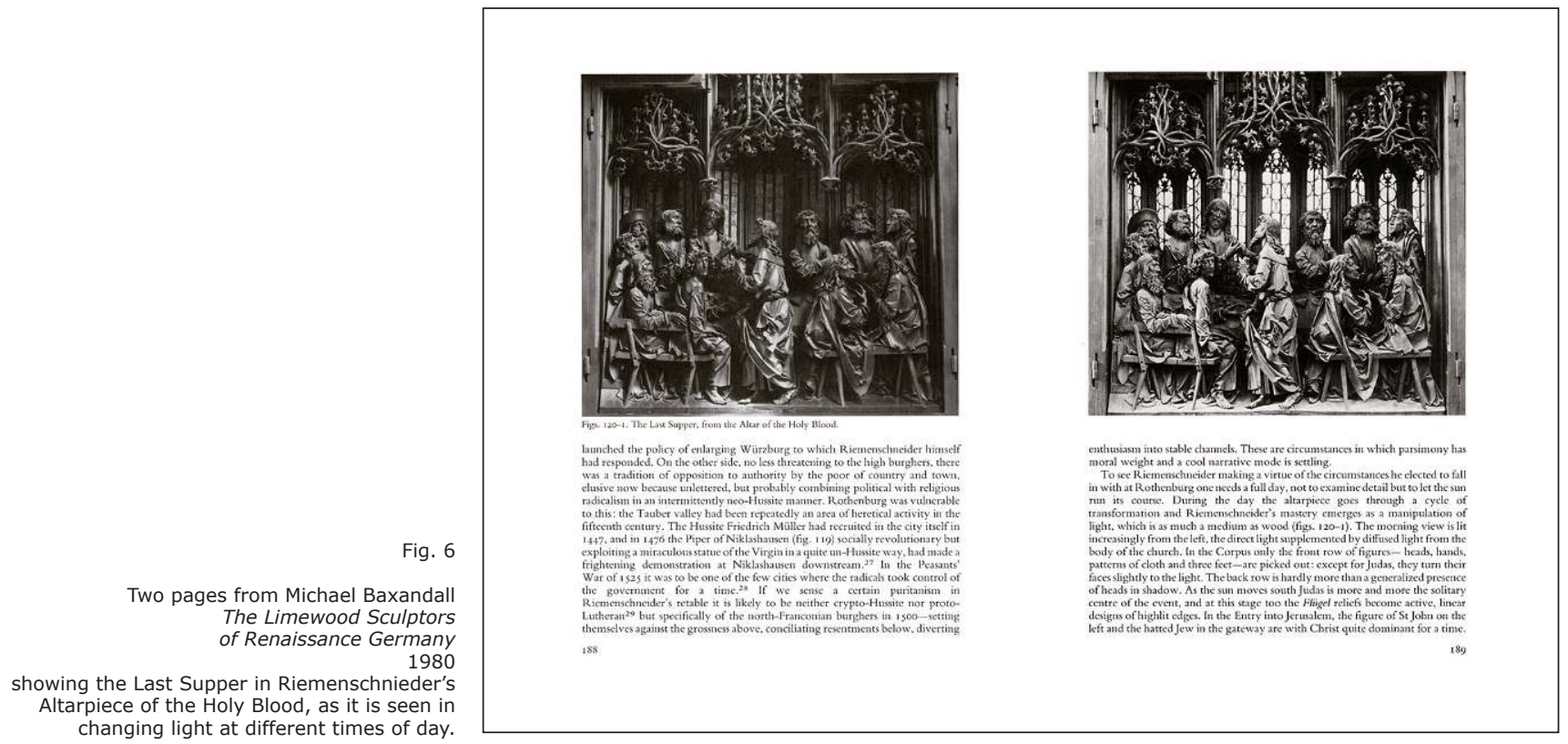

One notable contribution here was made by Michael Baxandall in his remarkable The Limewood Sculptors of Renaissance Germany - one of many discussions by this author of the viewer's responses to works of art. Discussing Michel Erhart's Schutzmantal Madonna, he coins a telling phrase about the sculpture's "arc of address", suggesting the relationship between viewers and the figure. Elsewhere, he described at length how viewing Riemenschneider's Holy Blood Altar is seen differently as the light changes within the chapel during the course of the day (fig. 6). ${ }^{44}$ Other scholars have attended to (actually a very Baxandallian phrase) the responses of viewers to sculpture in rather different ways. Among these contributions have been Betsy Rosasco's interpretation of the unsaid meaning of the Latona fountain in terms of the court game of the "enigma" and Genevieve Warwick's reading of Bernini's Daphne and Apollo not only in terms of its placing within the room, suggesting how the viewer might have moved, but also its relationship with a mechanical automaton shown in the same space. ${ }^{45}$

The way in which sculptures are apprehended by viewers within spaces has more recently drawn increasingly on phenomenology and in particular the writings of Merleau-Ponty. Here the leading texts have been those by Rosalind Krauss and - especially - Alex Potts in The Sculptural Imagination, with its extended and subtle discussions of how particular sculptural works are viewed. ${ }^{46}$ Being alert to the viewer's somatic responses, perhaps drawing on writing about the senses, such as Michel Serres's The Five Senses, allows us to think about the relationship

44. M. Baxandall, Limewood Sculptors, op. cit. note 35, p. 166

45. Betty Rosasco, "Masquerade and enigma at the court of Louis XIV" Art Journal, 48 (1989), pp. 144-149; Genevieve Warwick, Bernini: art as theatre, New Haven and London, Yale University Press, 2012.

46. Alex Potts, The Sculptural imagination: figurative, modernist, minimalist, New Haven and London, Yale University Press, 2001. 
between the viewer and sculptures of different periods in new ways. Indeed, one of the strengths of Potts's work is that he addresses sculpture by Canova as well as work by Tony Craggs.

\section{Conclusion: Curatorial choices and possibilities}

Referring to discussions and displays of sculptures by Riemenschneider, Daucher, Bernini, Pigalle, Canova, Rodin and Judd, along with many antique works, I have attempted to map out some of the ways in which the display and viewing of sculpture has been explored in recent studies. Some of these texts have dealt with sculpture displays within museums but many have been concerned with the staging of sculpture in settings outside the museum. But - and here we come to the central question - how might a sculpture curator take account of such approaches in planning displays within the modern museum, with all its constraints, contingencies and possibilities?

Sculpture created explicitly for gallery settings - what I have termed sculptures made as autonomous aesthetic objects - are in a sense relatively straightforward in that the museum setting is not too dissimilar from that of the galleries in which they were originally shown. But how might the domestic setting in which a terracotta - by Clodion, for instance - was displayed be suggested? And how might sculptures for public settings - squares or gardens - be shown, so that a viewer is made aware of the work's original function and context? This is still more difficult in the case of sculptures intended for devotion, especially when these survive in a fragmentary form, such as parts of altarpieces by sculptors such as Riemenschneider or Paul Egell. There are also questions of scale involved here, especially when gallery spaces diverge markedly from that of a sculpture's original context. Another disparity arises because of the way in which the arrangement of modern museums rarely encourages, say, the juxtaposition of modern works with the antique, as they were often arranged in the seventeenth and eighteenth centuries. Furthermore, how might we introduce into displays the narratives of making? And, above, all how might we suggest the original contexts of sculptures, along with their attendant meanings? One possibility of course are lengthy text panels but how can these work without distracting from the sculptures themselves? Such questions (and many others) are among the daily dilemmas facing any sculpture curator.

Here we might return to the V\&A and how some of these issues have been addressed in some recent opened galleries there. Ironically, but significantly, the challenges of displaying sculpture meaningfully perhaps come more clearly into view in a collection in which sculpture forms but one part, so raising the question of what a sculptural object is and how it might be displayed and viewed. This relationship between sculpture and related objects was dealt with in two ways, for example, in the V\&A's British Galleries, opened in 2004. ${ }^{47}$ In one gallery Bernini's Bust of Mr Baker shown as part of a display about Charles I's artistic patronage (fig. 7). While this display makes sense in terms of rich and complex interconnections between works commissioned or collected by the royal court, has the power that this remarkable sculpture still has for the viewer been sacrificed to the narrative of the display? Another set of juxtapositions involving sculpture is seen in a display bringing together eighteenth-century portraits in many media. Here the display does not attempt to suggest contemporary viewing conditions but nonetheless makes visible the diversity of portraiture so characteristic of eighteenth-century British culture, thus suggesting a wider cultural context for the ivory portrait relief and the portrait bust. 

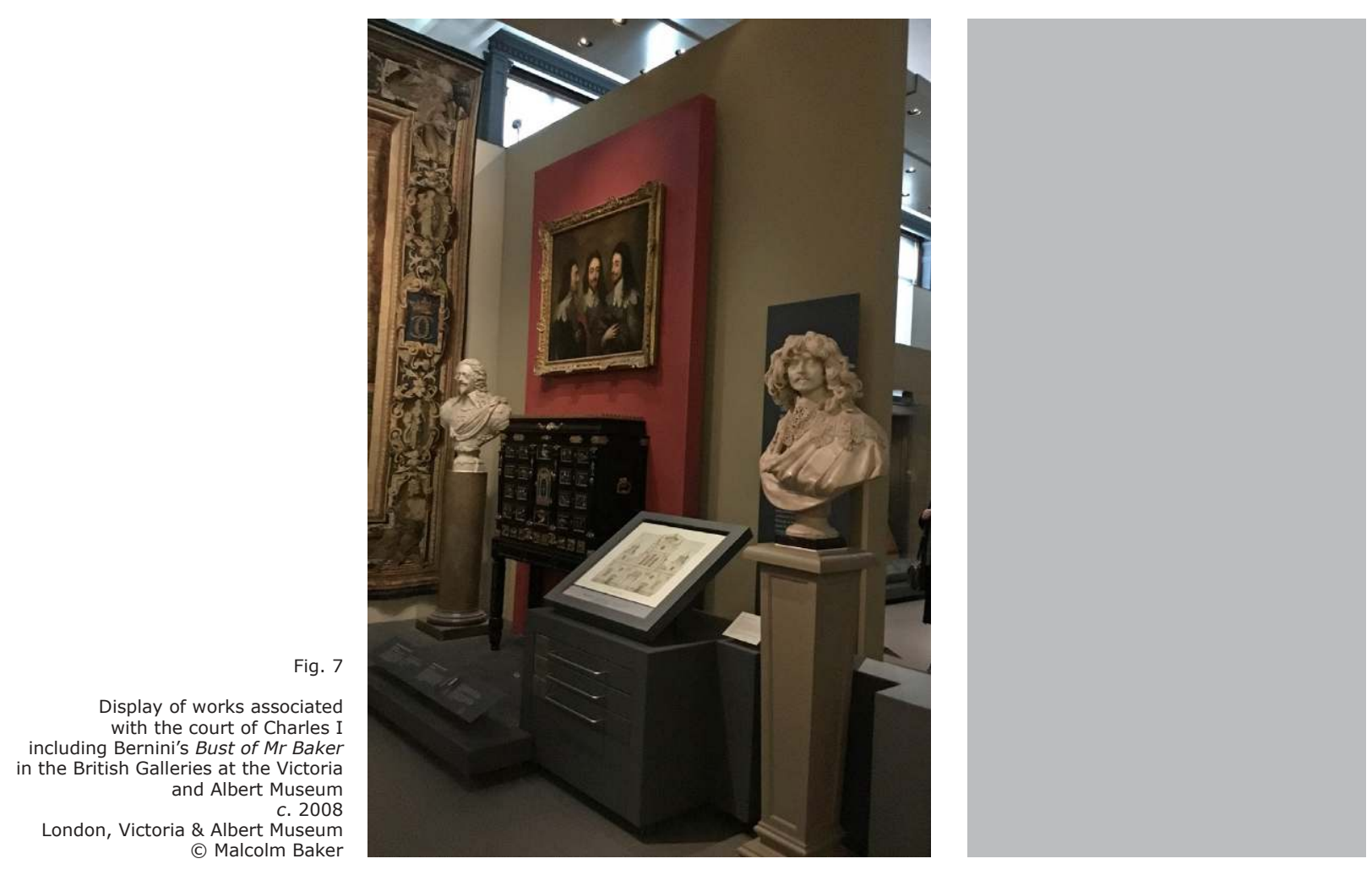

Still more recently sculpture figured prominently in the new Medieval and Renaissance Galleries (fig. 8). Here sculpture is neither shown separately from other classes of object or image nor simply placed alongside other types of work from as an illustration of a shared period style. On the other hand, the displays take account of the need to view sculpture in a way that assumes a complex interaction between sculpture and viewer. Put in another way, these displays confront the dilemma of displaying sculptures made for a now distant function and context in a gallery setting associated with the viewing of autonomous works of art. Central to these displays in rooms which vary greatly in size is an attempt to use spaces to suggest (but not replicate) earlier contexts. The largest space with the sequence thus moves from a secular, court-like setting (including fountain and free standing sculpture by Giambologna among other sculptors) to an area with works which have more ecclesiastical associations and functions. Then the viewer is encouraged to move into a section of the gallery, with lower light levels, with altarpieces gathered together as a genre and from there proceed to a more obviously church-like interior, culminating in the (re-contextualised) apse of a Renaissance church. Elsewhere, sculpture is incorporated into an intimate display suggesting (though not reproducing) a studiolo, where the intention has been to respect the optimum viewing conditions for the appreciation of the sculptures while making clear the intellectual, as well as the physical, contexts in which such works operated. In the case of Daucher's St John, mentioned earlier, the historical fact that the figure was from the start a fragment allows it to be shown as an isolated sculpture, though placed alongside texts and images illustrating those Reformation ideas connected with its life as a fragment. Here then are some possible ways of taking account of the shifts in scholarship and approach which I outlined earlier. But what remains central is the need to create conditions for close and sustained viewing. Most important of all must be a continuing recognition of sculpture's power to enthral and engage.

In this paper I have purposely moved to and fro between writing about displays of sculpture - usually historical accounts of interiors incorporating sculpture - and the strategies adopted by curators in displaying sculpture. Just as there is a dialogic relationship between the texts about the history of art and those histories of art constructed through museum displays, so displays of sculpture within museum settings are, in various ways, a response to the manner in which sculpture was originally displayed. Sometimes the original functions and contexts of sculpture 
are rejected or marginalised and sometimes, especially more recently, these earlier contexts are simulated or suggested. Whether writing about historical displays or creating new displays within the spaces of the museum, historians of sculpture necessarily engage with the complexities and ambiguities of de-contextualisation and re-contextualisation, whether on the page or in the gallery.

Fig. 8

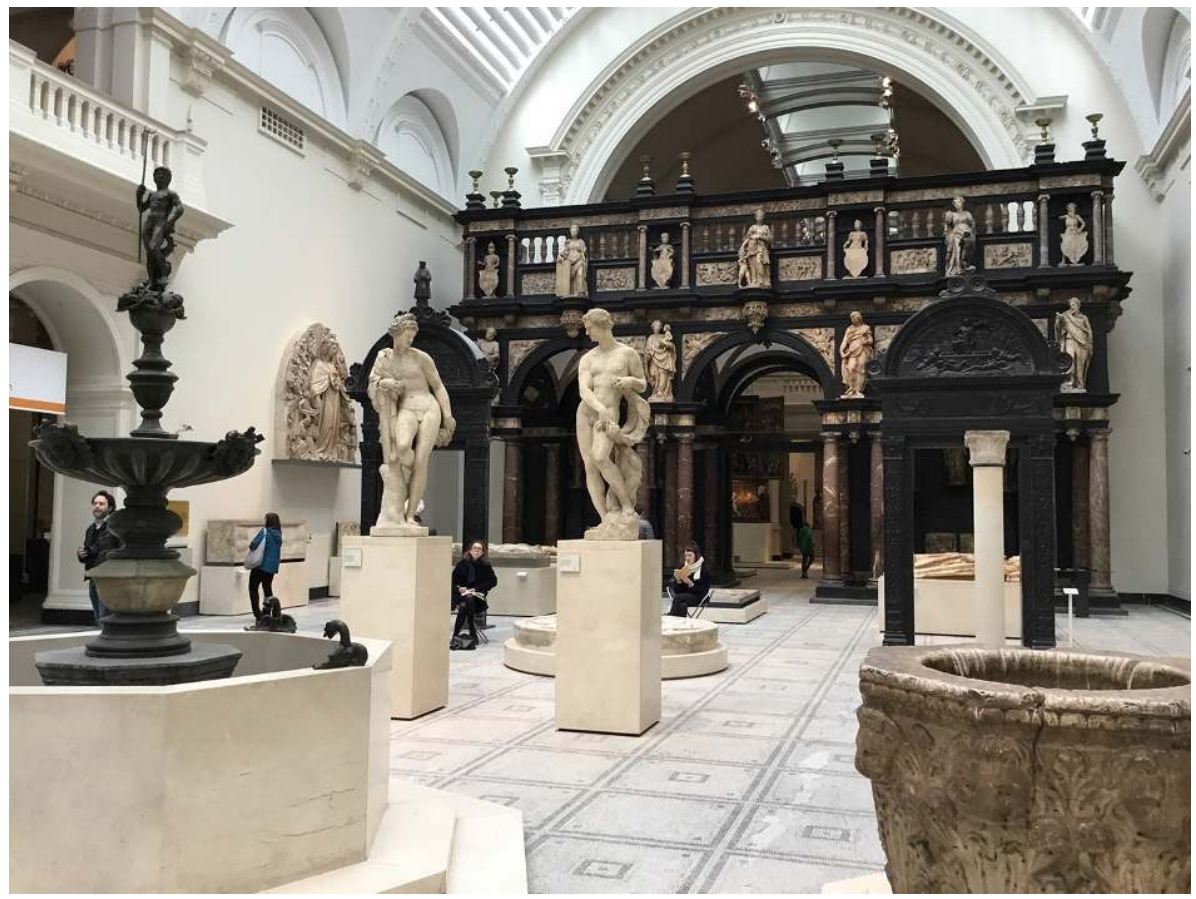

The author

Malcolm Baker is Distinguished Professor of the History of Art, the University of California, Riverside. He has worked both as university teacher in the UK (University of York) and USA (UCR and the University of Southern California) and as a curator at the Victoria and Albert Museum where he led the team planning the Medieval and Renaissance Galleries and curated the exhibition, A Grand Design. The Art of the $V \& A$ about the formation and display of the museum's collection. Though initially as a medievalist, he has written mainly about eighteenth-century sculpture. Among his books are Roubiliac and Eighteenth-Century Monument (1995), co-authored with David Bindman and awarded the 1996 Mitchell Prize for the History of Art, and Figured in Marble: the Marking and Viewing of Eighteenth-Century Sculpture (2000). His catalogue, Fame and Friendship. Pope, Roubillac and the Portrait Bust, appeared to accompany an exhibition shown in 2014 at the Yale Center for British Art and Waddesdon Manor and his 420 page study of the bust and the statue as genres - The Marble Index. Roubiliac and Sculptural Portraiture in Eighteenth-Century Britain - was published by Yale University Press in 2015. 